\title{
The Relationship Between Digital Literacy and Learning Outcomes in Biology Learning for Students
}

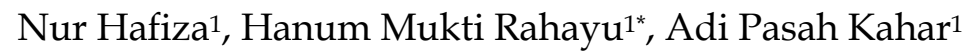 \\ ${ }^{1}$ Biology Education Program, Faculty of Teacher Training and Education, University of Muhammadiyah Pontianak, Indonesia.
}

DOI: $10.29303 /$ jppipa.v8i1.1067

\section{Article Info}

Received: October 27, 2021

Revised: December 29, 2021

Accepted: January 11, 2022

Published: January 31, 2022

\begin{abstract}
The study aims to determine the relationship between digital literacy and the learning results on the biology of class vii for the 12th country school class vii. This type of research is a quantitative study with a correlational method. The population in this study is class vii in the 12 countries' middle schools. The samples used in this study number 88 students. Research instruments using tankettes. The data analysis technique used is by using a product-moment correlation. Studies show the class vii c, d, e, and f's digital literacy of class vii c, d, e, and f get an average of 60.77 present in the moderate category. In contrast, the results of the student biology study of students get an average of 68.02 gifts in the intermediate class. Product correlation analysis between $x$ variables and $y$ variables show that $r$ recount $(0.290)>t$-table $(1.987)$ so that there is a link between digital literacy and the study of the biological student vii class 12 countries.
\end{abstract}

Keywords: Relationship; Results learning; Correlation digital literacy

Citation: Hafiza, N., Rahayu, H. M., \& Pasah Kahar, A. (2022). The Relationship Between Digital Literacy and Learning Outcomes in Biology Learning for Students. Jurnal Penelitian Pendidikan IPA,8(1), 171-176. https://doi.org/10.29303/jppipa.v8i1.1067

\section{Introduction}

Literacy is a person's ability to use the potential and skills in processing and understanding information when doing reading and writing activities. However, literacy is not just the ability to read and write; but literacy can mean literacy in technology, politics, critical thinking, and sensitivity to the surrounding environment. Thus, the importance of literacy and awareness of being literate will greatly support one's success in dealing with various problems (Oktariani, 2020).

Students' digital literacy skills in Indonesia are still deficient (Perdana, 2020), where mastery of literacy is also an important indicator to improve the achievements of the younger generation in achieving success (Asrizal, 2018). The generation that grew up with unlimited access to digital technology has a different mindset from the previous age. One of them is digital literacy; every individual needs to understand that digital literacy is an important thing needed to be able to participate in today's modern world. Digital technology allows people to interact and communicate with family and friends in everyday life. The existence of a digital literacy movement in schools is undoubtedly related to students who need to improve their skills in developing a school's digital literacy culture (Kemendikbud, 2017). In addition, a good education is also an investment and a means to print quality human resources (Zuhara, 2019).

Digital literacy was first suggested by Gilster (1997), which explains that digital literacy is the ability to use technology to locate, access and select information from various digital sources efficiently (Kurnianingah, 2017). Digital literacy has now become a necessity in learning activities (Amin, 2020). How much more modern learning has changed beyond the predictions of the covid-19 plague has brought urgent changes to different sectors (Khasanah, 2020). Especially in the field of education, which aims to build or form humans who have knowledge (Taofiq, 2018), governments aim for such teachers as educators and Learners can still arrange for teaching lessons in a different way. The ministry of education in Indonesia continued to be conducted with another system of study from home (SFH) (Salsabila, 2020). The performance of this learning certainly does not go unnoticed by digital technology. Digital media use will 
make it easier for students to search for sources of information and communication both personally and in the learning process.

Research done by Nugroho (2020) suggests that the city of Pontianak is one of the cities where the youth's digital literacy index goes into the higher category of level 3 advance (73.01\%-100\%). But from the pontifex dimension, one of the cities with low consumption levels will eventually affect the outcome of learning. This is enhanced by Giovanni statement (2019:160) that digital literacy ability will affect and that there is a significant link between digital literacy and student study. Student learning outcomes can be known through class assessment (Agustanti, 2012).

The 12-state high school of the 12 cities of the Pontianak is one of the state-based schools located in the west Pontianak region with accreditation and already have a computer laboratory of Internet support infrastructure such as wi-fi asa network for Internet access. At the country's 12 Pontianak already are facilitated in computers and the Internet to promote online study (Kurniawati, 2018) by utilizing digital media as a means to improve the quality of education and student knowledge (Rusydiyah, 2020). However, according to the interview with the country's 12 cities junior biology teacher, although the biology study process takes place online, there are still a few obstacles between student learning and student learning. It will be further studied whether this lack of knowledge is influenced by the inability of learners to understand the use of digital literacy itself or the lack of competence of learners because of the lack of awareness of learners. Herlina (2015) explains that digital literacy in biology study is crucial. Digital literacy involves digital action that is tied to the study of biology. Furthermore, digital literacy also consists of the ability to use knowledge, attitudes, techniques and personal qualities to solve the problems of biology study.

\section{Method}

The method used in this study is a correlational research method with a quantitative research approach. Using product-moment data analysis techniques. The study was held at state junior high in June 2021 online.
The samples in this study number 88 people. Data were obtained from the Google form for digital literacy filtering. Then the document on the teacher with the daily exam value data of biology subjects.

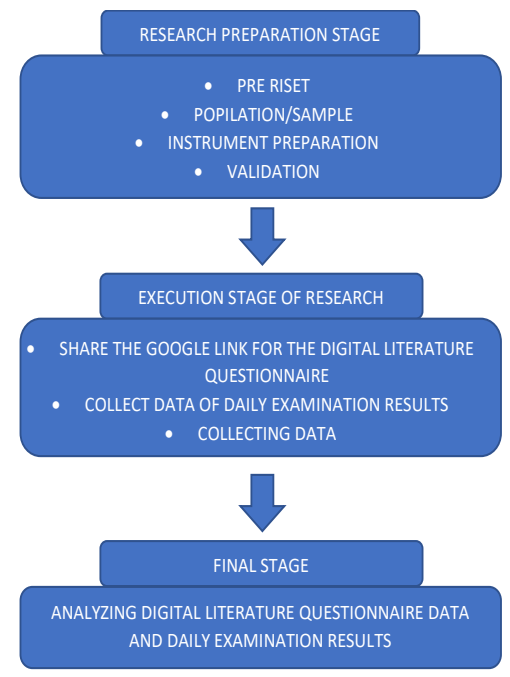

\section{Result and Discussion}

The Digital Literacy Ability of VII graders of SMP Negeri 12 Pontianak City in this study was obtained from digital literacy questionnaires. In contrast, the data obtained through documentation was data on the learning outcomes of grade VII students of SMP Negeri 12 Pontianak.

Table 1. Digital Literacy Questionnaire Data (Variable X) and Learning Outcome Data (Variable Y)

\begin{tabular}{lllll}
\hline \multirow{2}{*}{ Class } & \multicolumn{2}{c}{ Digital Literature } & \multicolumn{2}{l}{ Learning Result } \\
\cline { 2 - 5 } & Average & Category & Average & Category \\
\hline VII C, D, & \multirow{2}{*}{60.77} & Low & 68.02 & Low \\
E, and F & & & & \\
\hline
\end{tabular}

The table above shows that the digital literacy abilities of grade VII C, D, E, and F students get an average of 60.77 in the medium category. The biology learning outcomes of grade VII C, D, E, and F students get an average of 68.02 is in the medium category.

Table 2. Relationship of Research Variables/Sub Variables

\begin{tabular}{|c|c|c|c|c|}
\hline Correlation & $\mathrm{r}$ & $t_{\text {count }}$ & $\mathrm{T}_{\text {table }}$ & Relationships \\
\hline X: Digital Literacy with Y: Learning Outcomes & 0.290 & 2.933 & 1.987 & Low \\
\hline $\begin{array}{l}\text { X1: Intensity of Application and Utilization of Digital Literacy in Learning } \\
\text { Activities with Y: Learning Outcomes }\end{array}$ & 0.209 & 1.982 & 1.987 & Low \\
\hline $\begin{array}{l}\text { X2: Students Level of Understanding in Using Digital Media and the Internet } \\
\text { with H: Learning Outcomes }\end{array}$ & 0.184 & 1.736 & 1.987 & Low \\
\hline $\begin{array}{l}\text { X3: Level of Parental and Institutional Involvement in Digital Literacy } \\
\text { Development with Y: Learning Outcomes }\end{array}$ & 0.231 & 2.202 & 1.987 & Low \\
\hline $\begin{array}{l}\text { X4: Number of Presentations of School Information Using Digital Media or } \\
\text { Websites with H: Learning Outcomes }\end{array}$ & 0.226 & 2.151 & 1.987 & Low \\
\hline
\end{tabular}


Based on the results of data analysis, from the table above, it can be seen that the correlation coefficient of digital literacy product-moment with learning outcomes is 0.290 with significant test results obtained $t$ count 2.933 and $t$ table value 1.987 it can be seen that $2.933>\mathrm{t}$ table 1.987 so Ha is accepted. So, it can be said that there is a significant relationship between the variable $X$ of digital literacy with the variable $\mathrm{Y}$ of learning outcomes, and the correlation coefficient of 0.290 indicates the close relationship between the variables $\mathrm{X}$ and $\mathrm{Y}$ is a low relationship.

The existence of a relationship between digital literacy and learning outcomes is seen from the four indicators used, namely the Intensity of Application and Utilization of Digital Literacy in Learning Activities, Students' Level of Understanding in Using Digital Media and the Internet, Level of Parental and Institutional Involvement in Digital Literacy Development, and Number of Presentations. School Information Using Digital Media or Websites (Kemendikbud, 2017). Then it is in line with the results of Giovanni's research (2019), which states that digital literacy skills will have an effect, and there is a significant relationship between digital literacy and learning achievement, namely student learning outcomes. These learning outcomes are the results obtained from interaction and after going through learning activities (Hartina, 2020).

Furthermore, the results of the analysis of the relationship between the variables X1 Intensity of Application and Utilization of Digital Literacy in Learning Activities obtained the product-moment correlation coefficient $\mathrm{X} 1$ with learning outcomes is 0.184 with significant test results obtained $t$ count 1.982 and $\mathrm{t}$ table value 1.987 it can be seen that $0.184>\mathrm{t}$ table 1.987 so Ha is accepted. So, it can be said that there is a significant relationship between the variable $\mathrm{X} 1$ digital literacy with the $\mathrm{Y}$ variable learning outcomes, and the correlation coefficient of 0.184 indicates the close relationship between the $\mathrm{X}$ and $\mathrm{Y}$ variables is a low relationship.

Digital literacy is one of six basic literacy that is applied mainly in learning activities. In line with the results of Pratama's research (2019), In the indicator of the intensity of the application and use of digital literacy in learning activities, most of the students are in the poor category. However, in this case, with the help and application of internet digital media in biology learning, students have not been able to maximize the press to the maximum. So that the correlation coefficient of 0,184 is included in the low interpretation. Teachers must be creative by utilizing literacy media for learning (Ahmadi, 2018: 86). In addition, the teacher is also a determinant in determining the concept of learning to students by improving the quality of their learning (Haqiqi, 2018).
The ability to choose learning techniques and the teacher's ability to determine learning media dramatically determines the success of the learning process and the potential and skills of students (Rohwati, 2012). the teacher has an essential role in helping develop the various intelligence possessed by a student (Andima, 2021).

Furthermore, the results of the analysis of the relationship between the variables X2 Level of Student Understanding in Using Digital Media and the Internet obtained the product-moment correlation coefficient X2 with learning outcomes of 0.184 with significant test results obtained $\mathrm{t}$ arithmetic 1.736 and $\mathrm{t}$ table value 1.987 it can be seen that $0.184>t$ table 1.987 so Ha is accepted. So, it can be said that there is a significant relationship between the variable $\mathrm{X} 2$ of digital literacy with the variable $Y$ of learning outcomes, and the correlation coefficient of 0.184 indicates the close relationship between the variables $\mathrm{X}$ and $\mathrm{Y}$ is a low relationship.

Digital media has had a rapid influence on the education and learning system, so it is no stranger to academic and non-academic fields. Now, students' understanding of using internet digital media also occurs because of the shift in learning resources for students from physical learning sources (analogue media) to digital (Wahidin, 2018). This causes students during the Covid-19 pandemic to gain understanding and knowledge in learning through various online learning activities such as through applications, namely WhatsApp, Google Classroom, Zoom applications, Instagram applications, and others (Manurung, 2020). Based on the statement above, digital literacy skills are needed to quickly process learning information via the internet or other digital media. With the provision of digital literacy skills, it is hoped that students can have survival skills amid much information (Cahyati, et al., 2019). The more a person accesses the internet, gradually he will begin to understand which digital portals have good information quality and which digital outlets have low information quality (Sulistyo, 2013).

Furthermore, the results of the analysis of the relationship between the variables X3 Level of Parental and Institutional Involvement in Digital Literacy Development, the results of the product-moment X3 correlation coefficient with learning outcomes are 0.231 with significant test results obtained $t$ count 2.202 and $t$ table value 1.987 it can be seen that $0.231>\mathrm{t}$ table 1.987 so that $\mathrm{Ha}$ is accepted. So, it can be said that there is a significant relationship between the variable X3 digital literacy with variable $Y$ learning outcomes, and the correlation coefficient of 0.231 indicates the close relationship between variables $\mathrm{X}$ and $\mathrm{Y}$ is a low relationship. 
The involvement of parents in digital literacy education for children has not yet reached an agreement, such as: (1) There is an agreement between schools and parents for controlling healthy internet programs for children; (2) Availability of information from schools regarding content that is safe for children; (3) There is an agreement on time to surf the internet and alternative activities that children can choose when not playing gadgets; (4) Parents have not used parental control applications (Munawar, 2019). Davidson (2012) revealed that seeing the condition of students in Indonesia as a digitally native generation, parental assistance is needed when at home as a follow-up to learning at school. In addition, it provides many opportunities for students to be more active in building their knowledge (Aryana, 2016).

Furthermore, the results of the analysis of the relationship between the variables X4 Amount of Presentation of School Information Using Digital Media or Web Sites, the results of the product-moment correlation coefficient X4 with learning outcomes are 0.226 with significant test results obtained $t$ count 2.151 and $t$ table value 1.987 it can be seen that $0.226>t$ table 1.987 so that Ha is accepted. So, it can be said that there is a significant relationship between the variable $\mathrm{X} 4$ digital literacy with the variable $\mathrm{Y}$ learning outcomes, and the correlation coefficient of 0.226 indicates the close relationship between the variables $\mathrm{X}$ and $\mathrm{Y}$ is a low relationship.

The number of presentations of school information using digital media or websites obtained a correlation of 0.226 which shows a low relationship. In this indicator, two sub-indicators, namely schools, provide information through digital media and have social networking accounts to share biology learning materials. Students are not too enthusiastic about accessing learning information. This is because students are more interested in accessing unique, exciting and fun information on their social media. This is in line with Hanana's (2017) research which states that students prefer to open websites or social networks related to fun or leisure, such as opening music, movies or funny things. In the future, exciting learning content and school information will be essential for presenting information both on the website and on existing social media.

\section{Conclusion}

Based on the results and discussion as described above, it can be concluded that there is a relationship between digital literacy and learning outcomes in biology learning at SMP Negeri 12 Pontianak.

\section{Acknowledgments}

Thank you to the principal and biology teachers and seventh-grade students of SMP Negeri 12 Pontianak. They have been permitted to research at SMP Negeri 12 Pontianak so that this research can be completed.

\section{References}

Agustanti, T.H. (2012). Implementasi Metode Inquiry Untuk Meningkatkan Hasil Belajar Biologi. Jurnal Pendidikan Ipa Indonesia. 1(1), 16-20. https://doi.org/10.15294/jpii.v1i1.2007

Ahmadi, F., \& Ibda, H. (2018). Media Literasi Sekolah. Semarang: Pilar Nusantara.

Amin, I., M., Mansur, R., \& Sulistiono, M. (2020). Peran Literasi Digital Dalam Meningkatkan Pembelajaran Pendidikan Agama Islam. Jurnal Pendidikan Islam. 5(10), 58 - 67. Retrievd from. http://riset.unisma.ac.id/index.php/fai/article/v iew $/ 7700$

Andima, R., Sumarmin, R., Ahda, Y., Alberida, H., \& Razak, A. (2021). The Relationship between Multiple Intelligences and Biology Learning Outcomes of Student. Jurnal Penelitian Pendidikan IPA, 7(4), 625-631. https://doi.org/10.29303/ippipa.v7i4.778.

Aryana, I. G. M. R., Idrus, A. A., \& Harjono, A. (2016). Pengaruh Model Pembelajaran Kooperatif Nht Dan Stad Terhadap Hasil Belajar Pengetahuan Biologi Siswa SMA Negeri 2 Gerung. Jurnal Penelitian Pendidikan IPA, 2(2). https://doi.org/10.29303/jppipa.v2i2.41.

Asrizal, A., Amran, A., Ananda, A., Festiyed, F., \& Sumarmin, R. (2018). The Development of Integrated Science Instructional Materials to Improve Students Digital Literacy in Scientific Approach. Jurnal Pendidikan IPA Indonesia, 7(4), 442-450. https:// doi.org/10.15294/jpii.v7i4.13613

Cahyati, C., Surahman, E., Hernawati, D. (2019). Kemampuan Literasi Digital Dan Hasil Belajar Peserta Didik Melalui Model Discovery Learning. Prosiding: Seminar Nasional Biologi, Saintek, dan Pembelajaran (SN-Biosper).

Davidson, C. (2012). Seeking the green basilisk lizard: Acquiring digital literacy practices in the home. Journal of Early Childhood Literacy, 12(1), 2445. https:// doi.org/10.1177/1468798411416788

Gilster, P. (1997). Digital Literacy. New York: Wiley.

Giovanni, F. and Komariah, N. (2019). Hubungan Antara Literasi Digital Dengan Prestasi Belajar Siswa SMA Negeri 6 Kota Bogor. Libraria: Jurnal Perpustakaan, 7(1). 147-162. http://dx.doi.org/10.21043/libraria.v7i1.5827

Hanana, A., Pupita, Y., Marta, R., \& Elian, N. (2017). Pendidikan Media Literacy Pada Siswa/Siswi 
Smpn 10 Padang. Logista - Jurnal Ilmiah Pengabdian Kepada Masyarakat, 1(2), 58-66. https:// doi.org/10.25077/logista.1.2.58-66.2017

Haqiqi, L. Z., Ramdani, A., \& Zulkifli, L. (2018). Analisis Kemampuan Pendidik Dalam Menerapkan Penilaian Autentik Pada Mata Pelajaran Biologi Kelas X IPA SMA Di Kabupaten Lombok Timur. Jurnal Penelitian Pendidikan IPA, 4(1). https://doi.org/10.29303/jppipa.v4i1.60.

Hartina, L., Rosidin, U., \& Suyatna, A. (2020). Pengaruh Penerapan Instrumen Performance Assessment pada Pembelajaran IPA Berbasis Laboratorium Real terhadap Hasil Belajar Siswa. Jurnal Penelitian Pendidikan IPA, 6(1), 25-31. https://doi.org/10.29303/jppipa.v6i1.299.

Herlina, D. (2015). Membangun Karakter Bangsa Melalui Literasi Digital. Prosiding Seminar Nasional Kontribusi Ilmu-Ilmu Sosial dalam Percepatan Pembangunan Indonesia Bermartabat. Yogyakarta: UNY.

Kementerian Pendidikan dan Kebudayaan. (2017). Gerakan Literasi Nasional. TIM GLN Kemendikbud. Jakarta.

Khasanah, D.R.A.U., Pramudibyanto, H., \& Widuroyekti, B. (2020). Pendidikan Dalam Masa Pandemi Covid-19. Jurnal Sinestesia, 10(1), 41-48. Retrieved from https://sinestesia.pustaka.my.id/journal/article/ view $/ 44$

Kurnianingsih, I., Rosini, R., \& Ismayati, N. (2017). Upaya Peningkatan Kemampuan Literasi Digital Bagi Tenaga Perpustakaan Sekolah dan Guru di Wilayah Jakarta Pusat Melalui Pelatihan Literasi Informasi. Jurnal Pengabdian kepada Masyarakat (Indonesian Journal of Community Engagement), 3(1), 61-76. http://dx.doi.org/10.22146/jpkm.25370.

Kurniawati, N., Maolida, E., \& Anjaniputra, A. (2018). The praxis of digital literacy in the EFL classroom: Digital-immigrant vs digital-native teacher. Indonesian Journal of Applied Linguistics, $8(1)$,

28-37. https://doi.org/10.17509/ijal.v8i1.11459

Manurung, P. (2021). Multimedia Interaktif Sebagai Media Pembelajaran Pada Masa Pandemi Covid 19. Al-Fikru: Jurnal Ilmiah, 14(1), 1-12. https://doi.org/10.51672/alfikru.v14i1.33

Munawar, M., Fakhruddin., Rifai, A., \& Prihatin, T. (2019). Keterlibatan Orangtua dalam Pendidikan Literasi Digital Anak Usia Dini. Seminar Nasional Pascasarjana. Prosiding Seminar Nasional Pascasarjana UNNES. Retrieved from: https://proceeding.unnes.ac.id/index.php/snpas $\mathrm{ca} /$ article/view/272

Nugroho, C., Nasionalita, K. (2020). Indeks Literasi Digital Remaja di Indonesia (Digital Literacy Index of teenagers in Indonesia). Jurnal Pekommas. 5(2), 215223.

http://dx.doi.org/10.30818/jpkm.2020.2050210

Nurhasanah, S., Sobandi, A. (2016). Minat Belajar Sebagai Determinan Hasil Belajar Siswa (Learning Interest as Determinant Student Learning Outcomes). Jurnal Pendidikan Manajemen Perkantoran. 1(1), 128-135. https://doi.org/10.17509/ipm.v1i1.3264

Oktariani., \& Ekadiansyah, E. (2020). Peran Literasi dalam Pengembangan Kemampuan Berpikir Kritis (The Role of Literacy in the Development of Critical Thinking Abilitie). Jurnal Penelitian Pendidikan, Psikologi Dan Kesehatan. 1(1), 23-33.

Perdana, R., Jumadi, J., Rosana, D., \& Riwayani, R. (2020). The Online Laboratory Simulation with Concept Mapping and Problem Based Learning (OLS-CMPBL): Is It Effective in Improving Students' Digital Literacy Skills? Cakrawala Pendidikan, 39(2), 382-394. https://doi.org/10.21831/cp.v39i2.31491

Pratama, W. A., Hartini, S., \& Misbah, M. (2019). Analisis Literasi Digital Siswa Melalui Penerapan E-Learning Berbasis Schoology. Jurnal Inovasi dan Pembelajaran Fisika (JIPF). 6(1). 9-13. https:// doi.org/10.36706/jipf.v6i1.10398

Rohwati, M. (2012). Penggunaan Education Game Untuk Meningkatkan Hasil Belajar IPA Biologi Konsep Klasifikasi Makhluk Hidup. Jurnal Pendidikan IPA Indonesia, 1(1). https://doi.org/10.15294/jpii.v1i1.2017

Rusydiyah, E., Purwati, E., \& Prabowo, A. (2020). How To Use Digital Literacy as A Learning Resource For Teacher Candidates In Indonesia. Cakrawala Pendidikan, 39(2), 305-318. https:// doi.org/10.21831/cp.v39i2.30551

Salsabila, H.U., Irna Sari, L., Haibati Lathif, K., Puji Lestari, A., \& Ayuning, A. (2020). Peran Teknologi Dalam Pembelajaran Di Masa Pandemi Covid19. Al-Mutharahah: Jurnal Penelitian Dan Kajian Sosial Keagamaan, 17(2), 188-198. https://doi.org/10.46781/almutharahah.v17i2.138

Sugiono. (2013). Statistika Untuk Penelitian. Bandung: Alfabeta.

Sulistyo, B. (2013). Keilmuan Bidang Informasi Dan Perpustakaan. SulistyoBasuki's Blog: Library and Information Science.

Taofiq, M., Setiadi, D., \& Hadiprayitno, G. (2018). Implementasi Model Pembelajaran Inkuiri Dan Problem Based Learning (PBL) Terhadap Keterampilan Generik Sains Biologi Ditinjau Dari Kemampuan Akademik Siswa. Jurnal Penelitian Pendidikan IPA, 4(2). https://doi.org/10.29303/jppipa.v4i2.114 
Wahidin, U. (2018). Implementasi Literasi Media Dalam Proses Pembelajaran Pendidikan Agama Islam Dan Budi Pekerti. Edukasi Islami: Jurnal Pendidikan Islam, $7(02)$, 229-244. http://dx.doi.org/10.30868/ei.v7i2.284

Zuhara, E., Jufri, A. W., \& Soeprianto, H. (2019). Kemampuan Literasi Biologi Berdasarkan Gender Pada Siswa Peminatan Mipa Di SMA Negeri Kabupaen Lombok Barat.Jurnal Penelitian Pendidikan IPA, 5(1).

https://doi.org/10.29303/jppipa.v5i1.234 